Table 3. Room-temperature mechanical properties.

\begin{tabular}{|c|c|c|c|c|c|c|c|c|c|c|c|}
\hline \multirow{2}{*}{\multicolumn{2}{|c|}{ Specimens }} & \multicolumn{5}{|c|}{ As forged } & \multicolumn{5}{|c|}{ As heat-treated } \\
\hline & & \multirow{2}{*}{$\begin{array}{c}\begin{array}{c}\text { Hardness } \\
\left(\mathbf{H}_{\mathrm{B}}\right)\end{array} \\
98 \cdot 2 \\
98 \cdot 8\end{array}$} & \multirow{2}{*}{ 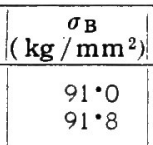 } & \multirow{2}{*}{$\begin{array}{c}\delta \\
(\%) \\
6 \\
6\end{array}$} & \multirow{2}{*}{$\begin{array}{c}\begin{array}{c}\psi \\
(\%)\end{array} \\
4 \\
8\end{array}$} & \multirow{2}{*}{\begin{tabular}{c|}
$\begin{array}{c}\mathrm{Kb} \\
(\mathrm{kg}-\mathrm{m})\end{array}$ \\
0.25 \\
0.43
\end{tabular}} & \multirow{2}{*}{\begin{tabular}{|c|}
$\begin{array}{c}\text { Hardness } \\
\left(\mathrm{H}_{\mathrm{B}}\right)\end{array}$ \\
$81 \cdot 2$ \\
$83 \cdot 6$
\end{tabular}} & \multirow{2}{*}{\begin{tabular}{|c|}
$\begin{array}{c}\sigma_{\mathrm{B}} \\
\left(\mathrm{kg} / \mathrm{mm}^{2}\right)\end{array}$ \\
$55 \cdot 3$ \\
$57 \cdot 1$
\end{tabular}} & \multirow{2}{*}{\begin{tabular}{|c|}
$\begin{array}{c}o \\
(\%)\end{array}$ \\
32 \\
36 \\
\end{tabular}} & \multirow{2}{*}{$\begin{array}{c} \\
(\%) \\
68 \\
70\end{array}$} & \multirow{2}{*}{$\frac{\mid \begin{array}{c}\mathrm{Kb} \\
(\mathrm{kg}-\mathrm{m})\end{array}}{\begin{array}{c}0.7 \\
2.6\end{array}}$} \\
\hline $\begin{array}{c}18 \mathrm{Cr} \\
(430)\end{array}$ & $\begin{array}{c}\mathrm{Ca}-\mathrm{Si} \\
\mathrm{RE}-\mathrm{Ca}-\mathrm{Si}\end{array}$ & & & & & & & & & & \\
\hline $\begin{array}{c}\text { Cr-Mn } \\
(202)\end{array}$ & $\begin{array}{c}\text { None } \\
\mathrm{Ca}-\mathrm{Si} \\
\mathrm{RE}-\mathrm{Ca}-\mathrm{Si}\end{array}$ & $\begin{array}{c}93 \cdot 1 \\
98 \cdot 2 \\
(100 \cdot 5)\end{array}$ & $\begin{array}{l}85 \cdot 9 \\
90 \cdot 2 \\
92 \cdot 2\end{array}$ & $\begin{array}{l}36 \\
25 \\
38\end{array}$ & $\begin{array}{l}66 \\
67 \\
69\end{array}$ & $\begin{array}{l}19 \cdot 6 \\
20 \cdot 5 \\
21 \cdot i\end{array}$ & $\begin{array}{l}85 \cdot 3 \\
88 \cdot 6 \\
88 \cdot 7\end{array}$ & $\begin{array}{l}70 \cdot 4 \\
69 \cdot 2 \\
73 \cdot 0\end{array}$ & $\begin{array}{l}59 \\
62 \\
69\end{array}$ & $\begin{array}{l}69 \\
71 \\
72\end{array}$ & $\begin{array}{l}28 \cdot 6 \\
29 \cdot 2 \\
29 \cdot 2\end{array}$ \\
\hline
\end{tabular}

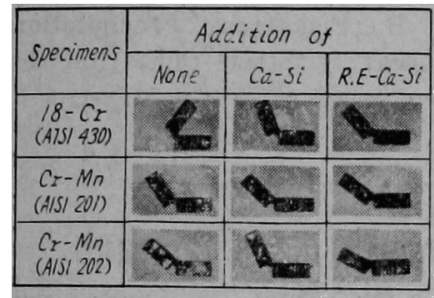

Photo. 1. Results of impactbending test at $1,200^{\circ} \mathrm{C}$.
理により熱間靬性 の改良が認めら れ, とくに $18 \mathrm{Cr}$ 系においては顕著 であつた。そのは か熱間引張, 熱間 捩り，熱間曲げ， クリープ試験など ね行つて, 同様比 較した. (5) その他の
性望

以上のほか各鋼種について JIS 法による耐硫酸試験， 粒界简食試験, 応力窝食割れ試耠の結果と, $\mathrm{Cr}-\mathrm{Mn}$ 系 の冷間加工率と磁性の関係などについて報告する予定で ある.
リープ試験片をつ くり, シャルピー 試験は, $-70^{\circ} \mathrm{C}$ より $100^{\circ} \mathrm{C}$ の範， 囲比いて行な い,クリープ破断 試験は $450^{\circ} \mathrm{C}$ 扰 よび $500^{\circ} \mathrm{C}$ に扰 いて行なつた.

\section{III. 実験結果}

（1）衝撃値に 扣よば方影響

value of $13 \%$ Cr steel.

Fig. 1 は加工度と墅撃值の関係を示したものである。 図にみるように峺撃値は加工度とともに増加し，35\%の 加工により約 $3 \mathrm{~kg}-\mathrm{m}$ 向上する.つぎに試験温度さ変 えて銜撃值き求め要移点さ検討してみると Fig. 2 亿示 すように, 普通焼入れの試料は約 $-40^{\circ} \mathrm{C}$ 亿遷移温度か

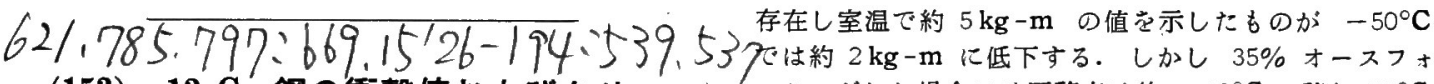
（153） $13 \mathrm{Cr}$ 鋼の街撃值およびクリーラ539ーミングした場合には僄移点は約 $-60^{\circ} \mathrm{C}$ に移り $20^{\circ} \mathrm{C}$ プ破断強さにおよぼすオース マ オーミングの影響

金属材料技術研究所

細 井祐三

Effect of Ausforming on Impact Value and Creep Rupture Strength of $13 \%$ Cr Stainless Steel.

$$
62305
$$

Yuzo HosoI

\section{I. 緒百 $1487 \sim 1488$}

準安定オーステナイト域において望性加工後烧入れる というオースフォーミング処理を $13 \mathrm{Cr}$ 鋼に施すとと 亿より耐食性な害するととなくり常温の機械的性質を向

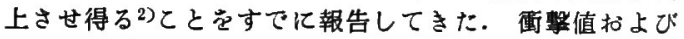
クリープ破断強さは鋼の低温求よび高温の強度む示す代 表的な值であり，一般に塑性加工により種々の影響てう けるので，本研究に括いてはさらに13Cr鋼のこれらの 珄實に拀よはすすオースフォーミングの影望を検討した。

\section{II. 実験試料および方法}

供武材は AISI 410 型ステンレス鋼に相する $13 \mathrm{Cr}$ 鋼 で主な化学成分は， $13.6 \% \mathrm{Cr} ， 0.15 \% \mathrm{C}$ であつた。

実験方法はすでにのべた方法2゙に準じたもので，950 ${ }^{\circ} \mathrm{C}$ においてオーステナイト化後, $450^{\circ} \mathrm{C}$ に急冷して同 温度で王延加工後焼入れ, ついで液体悬素に浸漬したの ち, 試験片を機械切削して,シャルピー試験片およびク
哇ど低温側にずれる。そして $-50^{\circ} \mathrm{C}$ に拈いても $4 \mathrm{~kg}$ $43 \mathrm{~lm}$ 以上の衝撃值き示した。

延性一脆性の僄移点を更に詳しくみるために $-50^{\circ} \mathrm{C}$ に扣りる衝撃試験後の破断面電子顕微鏡に上り観察す ると Photo. 1 (a) 打よび Photo. 1 (b) にみるよ うに, 普通焼入れの坛料の破断面 (Photo. 1 ( a )) は 脆生破面であることな示している。これに反しオースフ オーミングした試料の破断面 (Photo. 1 ( b ) ) は粒状 模样渵現わし延性的に破断したことさ明瞭に示してい る.

焼入れ後焼戾すと一般に㣫撃值は増すが，本実験の場 合も同様に焼戻し温度の上昇とともに衝撃值は増加す る.しかし $550^{\circ} \mathrm{C}$ まで焼戻すと湢撃值は急激に低下す

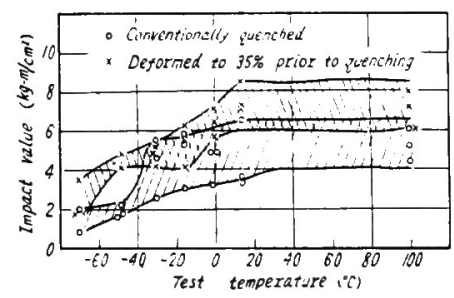

Fig. 2. Effect of test temperature on impact value of $13 \% \mathrm{Cr}$ steel. 


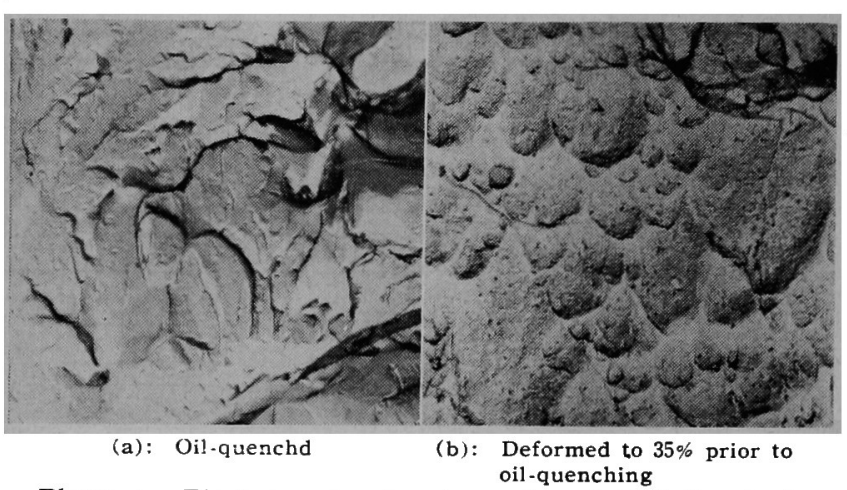

Photo. 1. Electron-microfractography of $13 \% \mathrm{Cr}$ steel fractured at $-50^{\circ} \mathrm{C}$.

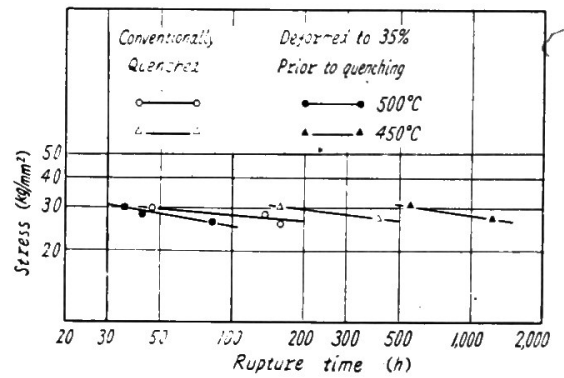

Fig. 3. Stress-rupture time relationship of $13 \% \mathrm{Cr}$ steel at $450^{\circ} \mathrm{C}$ and $500^{\circ} \mathrm{C}$.

る.これは炭化物の析出，凝集3によっ脆化のためと思 われ引.

（2）クリープ強さに扎よぼす影響

長時間の恒温焼㞔しを行いオースフォーミングの効果 が残る臨界条件さ求めた結果, $450^{\circ} \mathrm{C}$ 以下の温度ではか なり長時間オースフォーミングによる強化が残ることが わかったのミ，400 C 和よび500 C に扣いてクリープ 破断試験を行い高温における機械的性質に执よはすオー スフォーミングの効果さ調べた。 Fig. 3 はクリーフ破 断実釦の結果さまよめたもので，破断時間上負荷応力の 関係さ図示しけもものである。乙の実験に扰いて試験温度 $450^{\circ} \mathrm{C}$ の場合にはクリープ破断実験前に $500^{\circ} \mathrm{C}$ て $5 \mathrm{~h}$ の熱処理さ施し, 試験温度 $500^{\circ} \mathrm{C}$ の場合には, 試験前 に $500^{\circ} \mathrm{C} 24 \mathrm{~h}$ の熱処理菅行なつた. 図にみるように $450^{\circ} \mathrm{C}$ に扔いてはオースフォーミング処理によりクリー

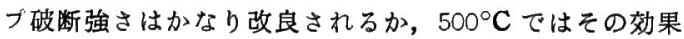
はすでに失われ逆に普通焼入れの場合の方がクリーブ破 断強さはよいようである。

\section{IV. 総}

\section{括}

オースフォーミング処理が $13 \mathrm{Cr}$ 鋼の低温ならびに 高温の機械的性賓におよばす影響を検討するために，衝 撃值およびクリープ破断強さに与える効果てしらべた。

室温の衝撃值はオースフォーミング処理により, 約 $35 \%$ の加工度を与えることにより, 約 $3 \mathrm{~kg}-\mathrm{m}$ 向上し, また透移点は約 $-40^{\circ} \mathrm{C}$ より約 $-60^{\circ} \mathrm{C}$ に移つた。

クリープ強さに与える効果は $450^{\circ} \mathrm{C}$ 以下で顕著であ

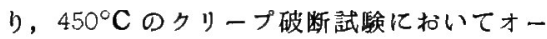
スフォーミングにより破断時間は長くなる

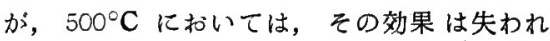
た.

以上の研究の結果オースフォーミングによ り $13 \mathrm{Cr}$ 鎆の衝撃值觉改良するととができる とともに $450^{\circ} \mathrm{C}$ 以下に打けるクリープ破断 強さ导毛改善できることがわかつた。

$$
\text { 文献 }
$$

1) 細井: 鉄と鋼, 47 (1961)，p.448

2) Y. Hosoi, K. E. Pinnow: Trans. Amer. Soc. Metals, 53(1961), p. 591

3 ) F. B. Pickering: Precipitation Process in Steels (The Iron \& Steel Inst.), (1959), p. 23

$669.14 .018 .8: 669,15^{\prime} 2 x^{\prime} 26-$
(154)

$192.49=539.56$

25Cr-20Ni 系ステンレス鋼に おける $\sigma$ 相の挙動

神戸製鋼所長俯北工場

工博 高橋 孝吉・大西 忠利 浜田 汎史・ ○大城 毅彦

Behavior of Sigma Phase in $25 \% \mathrm{Cr}-$ $20 \% \mathrm{Ni}$ Stainless Steel. $1488 \sim / 490$ Dr. Kokichi TaKahashi, Tadatoshi ONishi, Hirofumi HAMAda and Takehiko Oshiro.

\section{I. 緒}

オーステナイト系ステンレス鋼の優れた特性の多く は，と机オーステナイト単相であるてとに基くもので あるが，従来著者などはこの種ステンレス鋼の鋼管製造 工程中あるいは二次加工後に扣ける不適当な熱処理, な らゴにこれにつつくく高温での長期使用などが $\sigma$ 相の析出

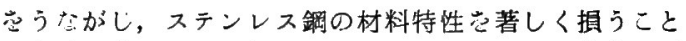
の意外に多いことを経験している.したがつて著者など は今後各種のオーステナイト系ステンレス鋼に打ける。 相の挙動について一連の調查忌行なう予定であるが, 今 回はいわゆる25-20ステンレス鋼について得た結果の一 部荤報告する.

\section{II. 供 試 材}

供武材としては $10 \mathrm{t}$ 塩基性電弧炉で溶製した鎆塊を 外径約 $160 \oint$ の鎆片に圧延し，乙れさ高温押出法によ つて押出加工後空冷した外径 $45 \mathrm{~mm}$ 肉厚 $5.5 \mathrm{~mm}$ の 継目無鋼管さ使用した，その化学成分は Table 1 のご とくである。

\section{III. 試験方法ならびに結果}

1) 固溶化処理材における $\sigma$ 相の挙動

上記押出鋼管について, $1000^{\circ} \mathrm{C}, 1100^{\circ} \mathrm{C}, 1200^{\circ} \mathrm{C}$, $1250^{\circ} \mathrm{C}, 1300^{\circ} \mathrm{C} / 1 \mathrm{~h}$, W. Q. の処理觉施した後, そ の各々について $800^{\circ} \mathrm{C}, 850^{\circ} \mathrm{C}, 900^{\circ} \mathrm{C} / 4 \mathrm{~h} \sim 100 \mathrm{~h}$, W. Q. の加熱觉重ね, 顕微鏡組織の観察と $2 \mathrm{~mm} \mathrm{U}$, ッチ巾 $2 \cdot 5 \mathrm{~mm}$ 試験片によるシャルピー 衝撃試験て行 なつた。そその結果では, $4 \mathrm{~h}$ 程度の再熱処理では $\sigma$ 相の 顕著な析出は認められず, 微細な $\sigma$ 相が炭化物と混在し 
Table 1. Chemical composition of test materials. (\%)

\begin{tabular}{r|l|l|l|l|l|l|l|l|l|}
\hline \hline Test materials & C & Mn & Si & P & S & Cu & Cr & Ni \\
\hline Steel & A & 0.05 & 1.75 & 0.24 & 0.024 & 0.012 & 0.10 & $19 \cdot 77$ & $25 \cdot 00$ \\
Steel & B & 0.11 & 1.98 & 0.53 & 0.024 & 0.044 & 0.09 & $18 \cdot 70$ & $23 \cdot 02$ \\
Steel & C & 0.14 & 1.99 & 0.73 & 0.028 & 0.066 & 0.10 & $19 \cdot 06$ & $23 \cdot 78$ \\
Steel & D & 0.17 & 1.88 & 0.59 & 0.028 & 0.005 & 0.11 & 18.97 & $23 \cdot 31$ \\
\hline
\end{tabular}

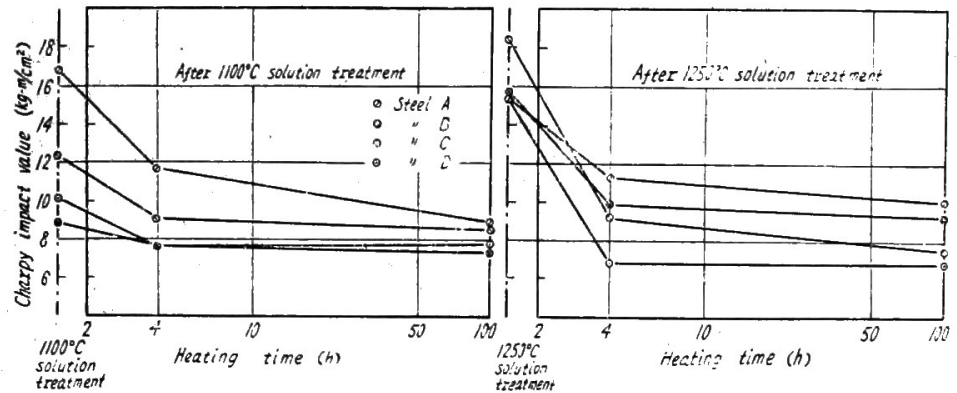

Fig. 1. Relationship between Charpy impact value and reheating time at $850^{\circ} \mathrm{C}$ (hot-extruded material).

よび諸温度に加熱保持後の組織さ 示す.また Photo. 2 に60\%加工 さ加え $100 \mathrm{~h}$ 加熱保持した後の組 織さ示す.

衝撃試臨の結果は $\sigma$ 相の析出粗 大化によつて著しい脆化が比較的 短時間内に発生すること示して いる. 衝撃值は高度の加工む加え たものでは加工直後は低い水準に あり $10 \mathrm{mn}, 1 \mathrm{~h}$ 加熱処理によつ て上昇する傾向にある。これは加 工歪の緩和によるものと思われ， $6 \mathrm{~h}$ 以上の加熱では急激な低下む 示し， $100 \mathrm{~h}$ まで加熱き続けると

たものと考えられる房状組織が見られるにすぎい。し かし $850^{\circ} \mathrm{C} / 60 \mathrm{~h}$ 以上加熱したものでは主として 結晶 粒界に粗大化した $\sigma$ 相が明瞭に認めら杭る. 衝撃值は 4 $\mathrm{h}$ 加熱で急激に低下し，更に $100 \mathrm{~h}$ 熱してもこの水準は わずかに低下するのみである.この衝撃值の低下は炭化 物の析出捛よび微量の $\sigma$ 相の析出によつて起るものと考 えられ, $100 \mathrm{~h}$ 保持でのゆるやかな低下は $\sigma$ 相粗大化に よるものと思われる. Fig. 1 亿衝撃試験結果さ示す.

2) 冷間加工材に扣ける $\sigma$ 相の挙動

上記押出鋼管穵板状として $1100^{\circ} \mathrm{C} / 1 \mathrm{~h}, \mathrm{~W} . \mathrm{Q}$. の 処理さ施した後，5\%，10\%，30\%，60\% の各圧下率で 冷間圧延觉行ない，乙れを $800^{\circ} \mathrm{C}, 850^{\circ} \mathrm{C}, 900^{\circ} \mathrm{C} / 10$ $\mathrm{mn} \sim 100 \mathrm{~h}, \mathrm{~W} . \mathbf{Q}$. の処理を施して供試材とし，顕微 鏡組織の観察と $2 \mathrm{mn} \mathrm{U}$ ノッチウ $2.5 \mathrm{~mm}$ 試験片による シャルピー衝撃試験を行なつた. この結果では, $1 \mathrm{~h}$ 加 熱保持後の $30 \%$ 加工材で, すでに局部的に相当量の $\sigma$ 相が析出しているのが琶められる. $60 \%$ 加工材では更に 多くの $\sigma$ 相が析出しているが， $5 \%, 10 \%$ 加工材では未 だ $\sigma$ 相の析出さ認めることができない. 加熱時間き $6 \mathrm{~h}$ にすると 30\%，60\% 加工材では更に多量の $\sigma$ 相が析出 し，10\% 加工材ではわずかにそれらしいものが慧めら れる程度である. 加熱時間さ更に $12 \mathrm{~h}, 24 \mathrm{~h}, 48 \mathrm{~h}$, $100 \mathrm{~h}$ として観察すると $30 \%, 60 \%$ 加工材では $\sigma$ 相析 出量の増加と共に, $1 \mathrm{~h}, 6 \mathrm{~h}$ 加熱後にはパーライト状あ るいは紐状觉星していた $\sigma$ 相が加熱時間の増加にともな つて塊状となつて成長するてとが認められる，一方 5 \%，10\%加工材に捄いては固溶化処理材と30\%，60\%加 工材との中間的様相を呈し冷間加工の影響はあまり顕著 にはあらわれない，本検鏡に扣いて $\sigma$ 相の析出初期で は, 再結晶粒々認められる部分に $\sigma$ 相の優先析出が明瞭 に観察された。これは $\sigma$ 相の析出と再結晶とは非常に密 接な関係を有すると云う LENA およびCURRY の報告邑 衰書きする事実である. Photo. 1 亿加工直後の組織㧍
この供試材における最大值の1/2程度まで低下する３0 $\%$ 冷間加工さ受けた steel Cłよび steel Dでは同様 の傾向导有するが同加工率のsteel A, steel B では 短時間の加熱によつても, 衝撃値の相当な低下が見られ る.とれはC量が高いために炭化物が粒界に比較的多量 に析出するこにによるものと思われる。組織との関迬か ら見ると, $1 \mathrm{~h}$ 加熱処理後の供試材で $\sigma$ 相の析出にもか かわらず㣫撃值の上昇が見られる他はすべて良い一致さ し， $\sigma$ 相の粗大化にしたがつて衝撃值が低下することは 明かである.Fig. 2，3 亿試験結果の一部さ示ず.

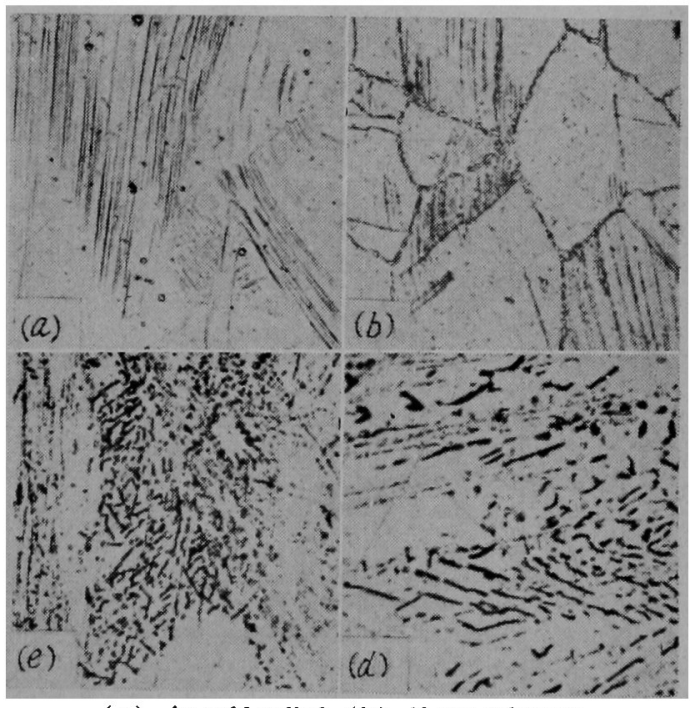

$\begin{array}{ll}\text { (a) As cold-rolled (b) } 10 \mathrm{mn} \text { reheated } \\ \text { (c) } 1 \mathrm{~h} \text { reheated } & \text { (d) } 6 \mathrm{~h} \text { reheated }\end{array}$

Photo. 1. Typical microstructures of steel D reheated at $850^{\circ} \mathrm{C}$ after $20 \%$ cold-rolle $?$. Etching solution used was $2 \mathrm{HCl}+1 \mathrm{HNO}_{8}$ +3 glycerin. $\times 800(2 / 3)$ 


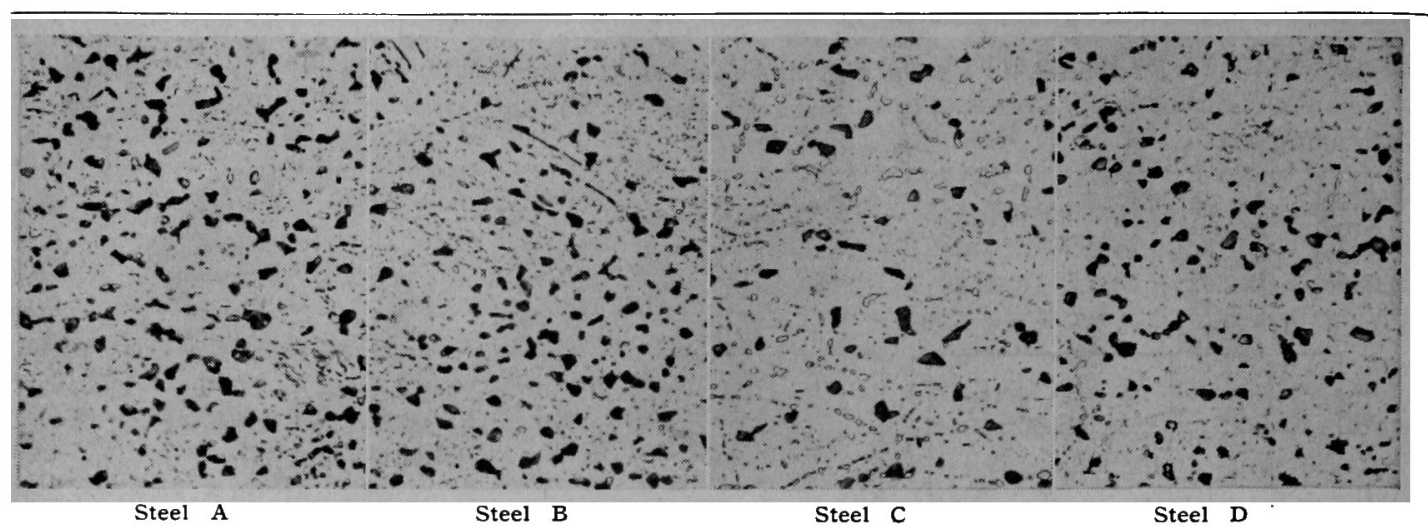

Photo. 2. Typical microstructures of steel A,B,C and D reheated at $850^{\circ} \mathrm{C}$ after $60 \%$ cold-rolling. Etching solution is $2 \mathrm{HCl}+1 \mathrm{HNO}_{3}+3$ glycerin. $\times 800(3 / 5)$

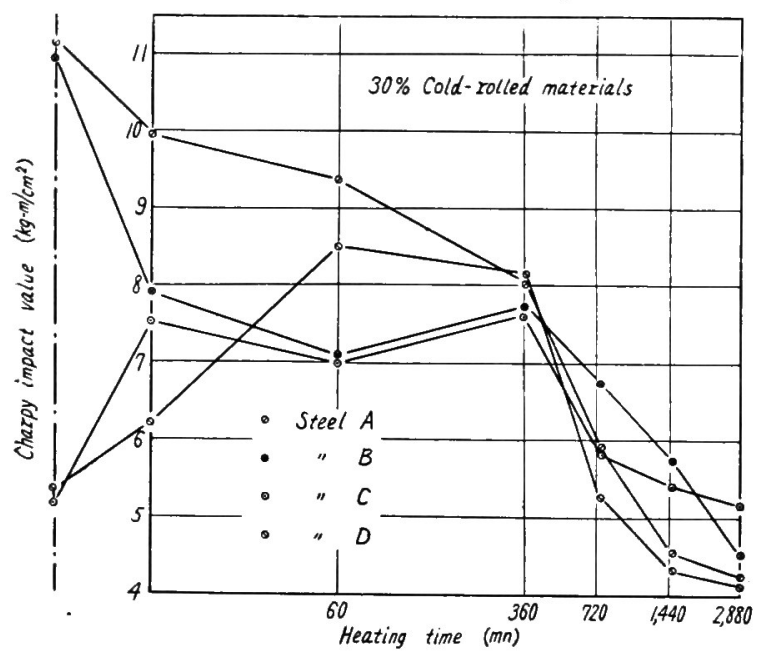

Fig. 2. Relationship between Charpy impact value and heating time at $850^{\circ} \mathrm{C}$.

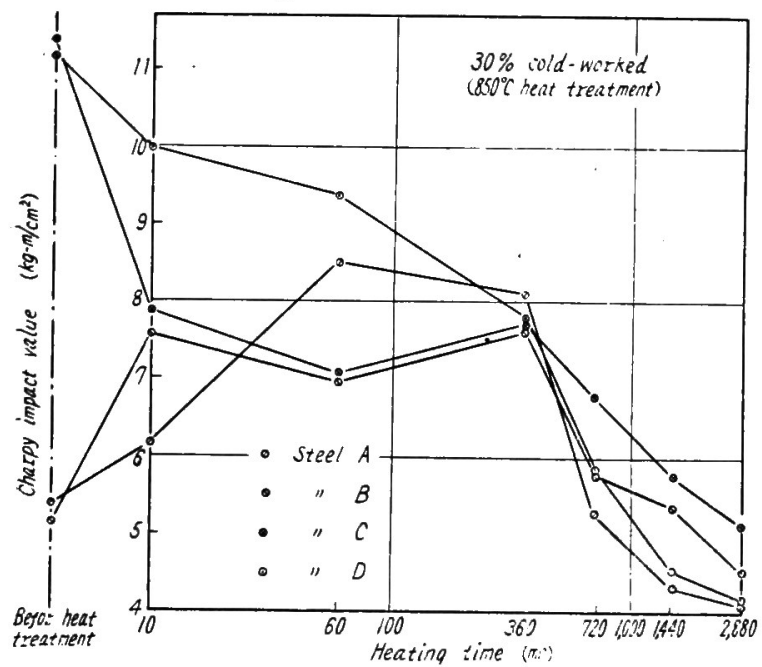

Fig. 3. Relationship between Charpy impact value and reheating time at $850^{\circ} \mathrm{C}$ (cold-rolled materials).
IV. 結

\section{言}

本実験で得られた結果は，1）C量の増加は $\sigma$ 相の析出を抑制する傾向がある，2）冷間加工の $\sigma$ 相析出促進作用はある特定の加工率以上で急激 に現われる，3）固溶化熱処理材では $\sigma$ 相析出は 冷間加工材に比べて顕著でない，4）㣫撃值の低 下は炭化物， $\sigma$ 相双方の析出によつて起るようで ある.などの諸点であるが本実験で観察した冷間 加工による $\sigma$ 相析出促進作用は LENA と CURRY によつて報告されているよりも大きく，垁用上相 当問題さ有するようである。な扮本稿では $\sigma$ 相の 影響さ材料の脆化佂ついてのみ取扱つたが，更に 耐食性に礼よぼす影響についても実験をすすめる 予定である。 
$1785-178-900.669: 12: 88 \div$

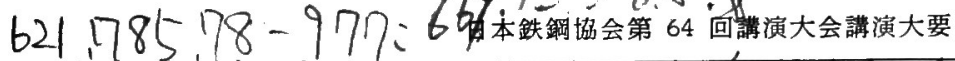

1491

(155)

669 容窒素316L 型鋼の機械的性質 におよぼす高温時効処理の影響

東京工業大学 62335

工博 岡本正三・工博○田中良平

藤本六郎・藤井 隆

Effect of High-Temperature Ageing Treatment on Mechanical Properties of High-Nitrogen $316 \mathrm{~L}$ Type Steels.

Dr. Masazō Oкамото, Dr. Ryōhei Tanaka, Rokurō Fujimoto and Takashi Fujı.

I. 結 言 $149 / \sim 1492$

筆者らはさきに, 高压窒素中溶解法菦用いて $316 \mathrm{~L}$ 型 銅に高濃度のNを含有せしめるこ常温扎よび高温の強度 は影著な改善さみるが, 高温に扣ける靱性がかなり減少 することを報告した1). また， $0 * 4 \%$ 以上の N 含む $316 \mathrm{~L}$ 型鋼を溶体化焼入して均一オーステナイト組織と したのち $600 \sim 1000^{\circ} \mathrm{C}$ で時効すれば, 窒化物 $\mathrm{Cr}_{2} \mathrm{~N}$ か いわゆる general precipitation 起してオーステナ イト粒界扰よび粒内一面に粒状に析出し，とくに800〜 $1000^{\circ} \mathrm{C}$ ではこの general precipițation に加えて grain boundary reaction 亿よる特徽的な㬝状組織が

発達するの琶めた。このように窒化物が 粒状あるいは圈状に析出した場合, その析 出様式や析出程度によつて鋼の機械的性實 はかなり影望されるであろうと考えられ， とくにての窒化物の析出状態总適当に調節 するととによつて前述の高温䩳性の欠乏を 改善し, 強度，歏珄のともにすぐれた材料 を得る可能性る期待される。そこで0・45〜 $0.50 \%$ のN含む $316 \mathrm{~L}$ 型鋼について種 々の高温時効処理によっ組織と機械的性貝 の変化き研究した.

\section{II. 試料と実験方法}

試料の溶製条件扣よび化学組成さ Table 1 に示した。溶解はいずれも 1 チャーシ5 $\mathrm{kg}$ として, $15 \mathrm{kVA}$ 高圧溶解炉さ用いて 窒素票囲気中で行ない, その需囲気のまま で約 $65 \mathrm{~mm}$ 角の銅製鋳型に鋳造した。鎆

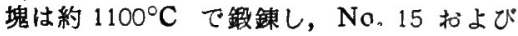
No. 16 は約 $15 \mathrm{~mm}$ 角のピレットとし, てれをさらに $1000^{\circ} \mathrm{C}$ で約 $6 \mathrm{~mm}$ 厚にま で熱間圧延した。.No. 56 は引張試験扰よ び衝撃試験に使用する関係から鉞錬で 13 $\mathrm{mm} \oint$ の丸棒とし，さらに9 $\mathrm{mm} \oint$ または 6.5 mm £にまで冷間引抜きした. 溶体化

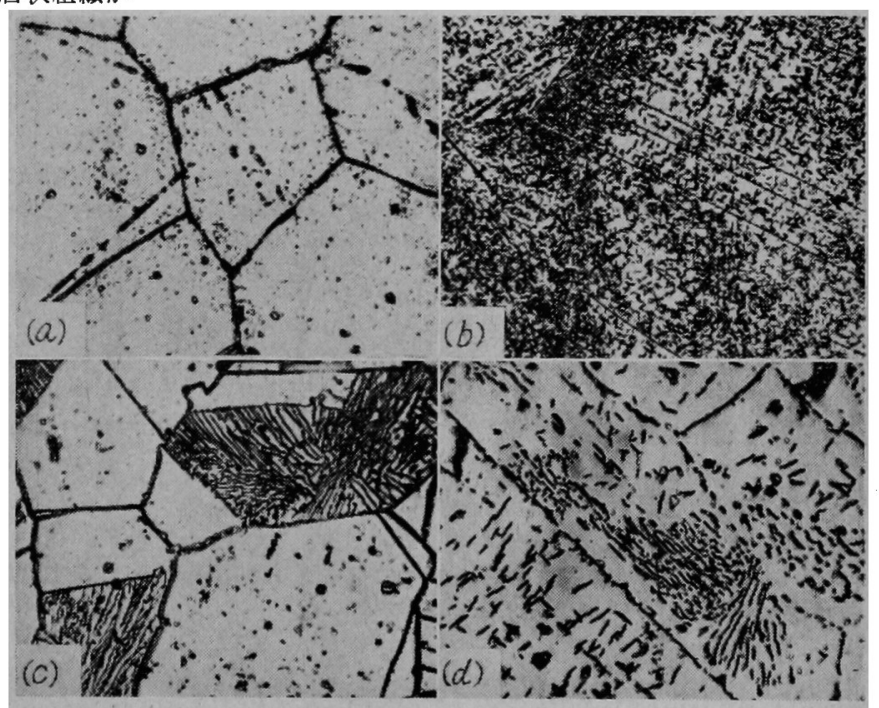

(a) Aged at $800^{\circ} \mathrm{C}$ for $3 \mathrm{~h}$ (b) Aged at $800^{\circ} \mathrm{C}$ for $1000 \mathrm{~h}$ (c) Aged at $900^{\circ} \mathrm{C}$ for $3 \mathrm{~h}$ (d) Aged at $900^{\circ} \mathrm{C}$ for $1000 \mathrm{~h}$

Photo. 1. Microstructures of type $316 \mathrm{~L}$ steels No. 15 aged at $800^{\circ} \mathrm{C}$ and $900^{\circ} \mathrm{C}$. (Electrolytically etched in $10 \%$ oxalic acid) $\times 400(2 / 3)$

Table 1. Chemical composition and melting conditions of the steels used.

\begin{tabular}{|c|c|c|c|c|c|c|c|c|c|}
\hline \multirow{2}{*}{ No. } & \multicolumn{2}{|c|}{ Melting condition } & \multicolumn{7}{|c|}{ Chemical composition (\%) } \\
\hline & $\begin{array}{c}\mathrm{N}_{2} \text { pressure } \\
\text { atm }\end{array}$ & $\begin{array}{c}\text { Holding time } \\
\text { mn }\end{array}$ & $\mathrm{C}$ & $\mathrm{Si}$ & $\mathrm{Mn}$ & $\mathrm{Cr}$ & $\mathrm{Ni}$ & Mo & Total $\mathrm{N}$ \\
\hline $\begin{array}{l}15 \\
16 \\
56\end{array}$ & $\begin{array}{r}10 \\
10 \\
7\end{array}$ & $\begin{array}{l}10 \\
10 \\
60\end{array}$ & $\begin{array}{l}0.004 \\
0.004 \\
0.005\end{array}$ & $\begin{array}{l}0 \cdot 45 \\
0 \cdot 38 \\
0 \cdot 35\end{array}$ & $\begin{array}{l}0.98 \\
0.97 \\
0.95\end{array}$ & $\begin{array}{l}16 \cdot 93 \\
18 \cdot 43 \\
17 \cdot 44\end{array}$ & $\begin{array}{l}11 \cdot 80 \\
11 \cdot 57 \\
11 \cdot 95\end{array}$ & $\begin{array}{l}1 \cdot 94 \\
1 \cdot 88 \\
1 \cdot 92\end{array}$ & $\begin{array}{l}0.461 \\
0.467 \\
0.504\end{array}$ \\
\hline
\end{tabular}




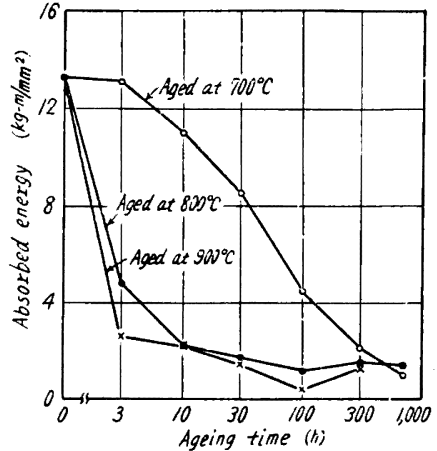

Fig. 1. Effect of high-temperature ageing treatment on impact properties of type $316 \mathrm{~L}$ steel No. 56.

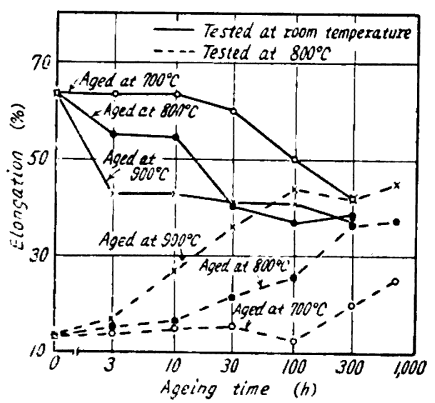

Fig. 2. Effect of high-temperature ageing treatment on elongation in tensile test of type $316 \mathrm{~L}$ steel No. $5 \dot{s}$.

はもはやあまり進行せずに㲜等さ炲め，かつ初期には明 暸に琵められた general precipitation 部との境界も 次第に消失する。

2. 硬度変化

$700^{\circ} \mathrm{C}$ 時効では時間とともに硬度增加が認められる が，ての硬化は Hv 20 程度に過ぎず，1000 h では過時

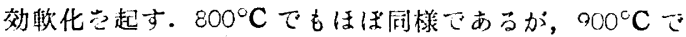
は $30 \mathrm{~h}$ 以上ですでに過時效となり，時閂とともに漱次 靯化する。

3. 常温衝整值の変化

Fig. 1 は No.56の各種時效処明志扰した $5 \mathrm{~mm} \oint$ 武

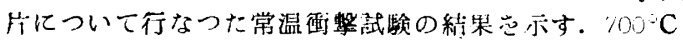

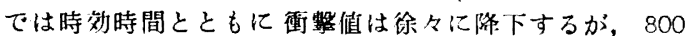

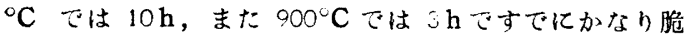
化し, 衝值は溶体化状態の約 $1 / 10$ にまで低下する。

その後は時間の経過にあまり関係なくはほ一定の低い遇 斩值心示す.

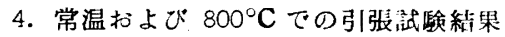

抗張力および耐力は常温, $800^{\circ} \mathrm{C}$ のずれでも時効温 度 $700^{\circ} \mathrm{C}$ の場合は時効時間とともにでくわずかに増加

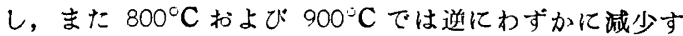
る. Fig. 2 は時効時間と伸びとの関係さ示したもので あるが，時効による伸びと紋りの変化はかなり顥著こ， 常温試験では両者とも溶体化状態が鼠高の值ひ示し，時
効温度の高いはど，また時効温度の長いはど伸び，较り

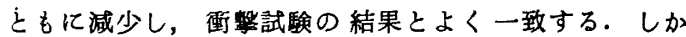
し, $800^{\circ} \mathrm{C}$ での引張試験結果はまつたく逆で, 溶体化試 料は伸び，絞りが少ないのに対し，時効時間の延長とと もに改善され，その傾向は時効温度の高いほどいちじる しく, とくに $900^{\circ} \mathrm{C} て ゙ 30 \mathrm{~h}$ 以上時効すると常温試験の 伸び，舷りの值を凌ぐはどに増加する.

こ机らの結果扣よび試験破断部附近の組織観察から， 常温引張試験では溶体化試料はオーステナイト中のN闾 溶度が高くても大きな変形能をもち，一方高温時効によ り窒化物が析出すると塑性変形能は害されるが， $700^{\circ} \mathrm{C}$ あるいは $800^{\circ} \mathrm{C}$ の比較的短時間の時効材では析出物が 微細かつ一様に分右して脆化は顕著でなく析出量の増加 とともに楥慢に勤性を減ずる. $900^{\circ} \mathrm{C}$ 時効材では層状窒 化物の析出により粒界强度が低下するもののようで, クラックは粒界に発生して伸び，絞りがいちじるしく減 少すると考えられる。

他方, 高温數性はオーステナイト中の固溶窒素量と密 接な関係があると思われ，固溶窒素が高温時効によつて 析出すればての析出形態や分布様式はどうあろうとも， 主として四溶壆素量の減少によつていちしるしく䩗性が 增加すると考えられる。

5. クリープ破断武験結果

No. 16 武料て $800^{\circ} \mathrm{C}$ 扰よび $900^{\circ} \mathrm{C} て ゙ 10 〜 300 \mathrm{~h}$ 時 効し, $700^{\circ} \mathrm{C}$, 忘力 $15 \mathrm{~kg} / \mathrm{mm}^{2}$ で試験した。時効温 度の高いほど，また時効時間の長いほど概してクリープ 速度は大となるが，比較的短時間の高温時効によつて䏢 断時間ははとんど変化せずに伸びがかなり改善せられ， さらに長時閏時効すると破断伸びはな初增加するが破断 時間はいちじるしく減少する。しかして析出样式の相遧 による影戀はあまり明らかでないが，窒化物がすでに多

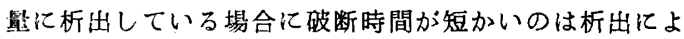
り素地のクリーブ抵抗が诚少するためで，破断時間が短 かくある程度未析出の $\mathrm{N} か ゙$ 素地中伐存固溶している状 惩では破断㶦命，伸でともにすぐれた性買さ示すものの ようである。

\section{IV. 結}

\section{言}

0.45 0.50\% の高濃度のN て等化物析出に上る機械的性質の変化をしらべたが, $700 \sim 900^{\circ} \mathrm{C}$ で高温時効処理によつて窒化物の析出様 式がから異なるにもかかわらず，析出様式が機械的性 䨘に扰よばす能響はあまり明らかでない。しかして上記 高温時効によつて常温, 高温の強度は大きな変化を示さ

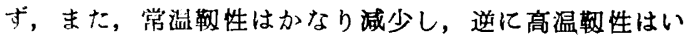
ちじるしく增加する.クリープ破断特性は時効時間が短 かくある秷度未析出のNが素地中に残存固溶している状 態で比較的すぐれた性質を示す.

\section{文献}

1) 岡本, 田中, 内藤, 藤本: 鉄と鋼, 48 (1962), p. 123 